\title{
Enhanced fluorescence of selected cationic dyes adsorbed on reduced charge montmorillonite
}

\author{
P. PUSTKOVÁ ${ }^{1 *}$, Z. KLIKA ${ }^{1}$, J. PRECLÍKOVÁ ${ }^{2}$, T. M. GRYGAR ${ }^{3}$ \\ ${ }^{1}$ Department of Analytical Chemistry and Material Testing, VŠB-Technical University of \\ Ostrava, 17. listopadu 15, 70833 Ostrava-Poruba, Czech Republic \\ ${ }^{2}$ Department of Chemical Physics and Optics, Charles University Prague, Ke Karlovu 3, \\ 12116 Prague, Czech Republic \\ ${ }^{3}$ Institute of Inorganic Chemistry AS CR, v.v.i., Husinec-Řež 1001, 25068 Řež, Czech \\ Republic
}

ABSTRACT: The aggregation of three cationic dyes (CD), crystal violet $(\mathrm{CV})$, Nile blue $(\mathrm{NB})$ and rhodamine $\mathrm{B}(\mathrm{RB})$ in aqueous solution was studied by Vis absorption spectrophotometry and compared with methylene blue (MB). The distribution of the dye species (monomers, dimers, trimers, and tetramers) in aqueous solutions with different concentrations of dye was calculated using equilibrium stepwise aggregation constants $K_{n}$. These cationic dyes were intercalated into montmorillonite (SAz-1) and its reduced charge form (RC-SAz(210)) prepared by heating lithium montmorillonite (Li/SAz-1) at $210{ }^{\circ} \mathrm{C}$. The fluorescence of fully saturated $\mathrm{CD} / \mathrm{SAz}$ and low CD loaded CD/RC-SAz(210) complexes was studied. Vis absorption spectra of $\mathrm{CD}$ aqueous solutions and Vis absorption spectra and X-ray diffraction 
pattern $\left(\mathrm{d}_{001}\right)$ of the $\mathrm{CD} / \mathrm{SAz}$ and $\mathrm{CD} / \mathrm{RC}-\mathrm{SAz}(210)$ solid complexes were obtained and evaluated. Huge fluorescence intensity was found for CV/RC$\mathrm{SAz}(210)$ and NB/RC-SAz(210) complexes similarly as with the complex of methylene blue with reduced charge montmorilonite $\mathrm{MB} / \mathrm{RCM}(210)$ described previously.

KEYWORDS: cationic dye, reduced charge montmorillonite, fluorescence.

\section{INTRODUCTION}

The cationic dyes (CD) methylene blue, crystal violet, Nile blue and rhodamine B form aggregates in concentrated aqueous solutions (Klika, 1979; Stork et al., 1972; Stužka \& Hanuš, 1980; Selwyn \& Steinfeld, 1972) and/or at the interface of cationic dye/clay mineral surface (Klika et al., 2004; 2007; Yariv \& Nasser, 1990). Two main types of dye aggregation can be observed, i.e. H-aggregates with head-to-head orientation and less frequent J-aggregates with head-to-tail orientation (Bujdák, 2006). A degree of aggregation of some CD (e.g. methylene blue, crystal violet, Nile blue) relates to dimers, trimers, tetramers and probably even higher polymers. Formation of the dye aggregates on clay mineral surface was described by Bergmann and O'Konski (1963) already more than 40 years ago. This interaction is related to colour change called metachromasy, a replacement of principal band of dye monomers in the visible region by band at a shorter 
(related to $\mathrm{H}$-aggregates) and/or longer (related to J-aggregates) wavelengths. The aggregation of dye in aqueous solution is influenced by concentration and type of dye (Klika, 1979; Stork et al., 1972; Stužka \& Hanuš, 1980; Selwyn \& Steinfeld, 1972), while in aqueous dispersion with clay mineral the dye aggregation run in larger extent and it is influenced also by its layer charge (Czímerová et al., 2006).

The layer charge is very important parameter of clay minerals determining their physical and chemical properties. The term "layer charge" includes both permanent and variable charge of clay mineral (Czímerová et al., 2006). The permanent charge arises from non-equivalent isomorphic substitution of the central atoms in octahedral and/or tetrahedral sheets. The variable, i.e. $\mathrm{pH}$ dependent charge occurs at specific functional groups (especially hydroxyl groups) on montmorillonite edges. These groups exhibit acid/base character. In smectites, the permanent charge is significantly higher than variable charge, and is compensated by exchangeable cations (e.g. $\mathrm{Na}^{+}, \mathrm{Ca}^{2+}$ ). The charge density in original smectites is so high, that common cationic organic dyes are heavily aggregated after complete exchanging small inorganic cations. To avoid his aggregation, the permanent charge can be reduced by Hofmann-Klemen effect (Hofmann \& Klemen, 1950) - heating the clay mineral at $200-300{ }^{\circ} \mathrm{C}$ after their exchange with small ionic radius, e.g. $\mathrm{Li}^{+}$that causes migration of the small dehydrated cations into pseudohexagonal holes of tetrahedral 
layers and vacant octahedral positions and consequently reduces the ionexchangeable layer charge (Komadel et al., 2005; Alvero et al., 1994). The extent of charge reduction depends on ion radius of intercalated cation, chemical composition of clay mineral, temperature and time of the heating (Madejová, 2005; Su \& Shen, 2005).

Many studies (e.g. Klika et al., 2004; Bujdák et al., 2001; 2002; Dobrogowska et al., 1991) have shown that the density of negative layer charge and/or dye concentration influence substantially the aggregation of intercalated dye. The clay minerals with high density of layer charge support the aggregation because of short distances between neighbouring adsorbed dye cations on clay surface; oppositely, low charge density of clay mineral limits the contact between neighbouring adsorbed dye cations and hence suppresses the dye aggregation (Bujdák et al., 1998).

The dye aggregation, the amount of dye (Endo et al., 1986; 1988; Klika et al., 2009) and orientation of dye molecules adsorbed on the surface (Sasai et al., 2004; Salleres et al., 2009) and/or in the structure of clay mineral (Villemure et al., 1986) influence the fluorescence of dye/clay mineral complexes. For example fluorescence band of fully saturated montmorillonite with methylene blue (MB) is wide and has a very low intensity. This intensity can be further decreased if the charge of montmorillonite is higher and more $\mathrm{MB}$ is inserted in the interlayer space (Klika et al., 2007). It is in agreement with Endo et al. (1988) who reported 
the fluorescence quenching due to the increasing amount of intercalated dye. The low fluorescence was recorded also for methyl red adsorbed on montmorillonite and vermiculite (Martynková et al., 2008) and for tetracationic porphyrin intercalated into the thin film of three smectites with high (fluorohectorite), medium (montmorillonite) and low layer charge (laponite) (Čeklovský et al., 2008). All these dye/clay complexes were probably prepared at full saturation of the clay minerals by dyes. Intercalation of $\mathrm{CD}$ from more concentrated aqueous solutions into clays results in the formation of dye J- and/or H-aggregates (Sasai et al., 2004). Whereas less frequent J-aggregates exhibit the fluorescence, the $\mathrm{H}$ aggregation quenches the fluorescence (Sasai et al., 2004; Salleres et al., 2009). Also iron present in clay mineral structure is an effective fluorescence quencher (Klika et al., 2009; Villemure et al., 1986).

Recently Klika et al. (2009) have confirmed that the layer charge of montmorillonite, concentration of $\mathrm{MB}$ in aqueous solution and low $\mathrm{MB}$ loading considerably influence the fluorescence of $\mathrm{MB} /$ montmorillonite complexes. The authors concluded that the reduced charge of montmorillonite $\mathrm{RCM}(210)$ with low loading of $\mathrm{MB}$ has huge fluorescence intensity after laser excitation (Klika et al., 2009). The fluorescence band of these complexes has a single sharp maximum, which matches to presence of dye monomers bonded on the montmorillonite surface. 
The aim of this paper is to check whether the reduced loading of dye enhances significantly the fluorescence of further dyes with different spectral properties. For this purpose $\mathrm{RCM}(210)$ complexes with other $\mathrm{CD}$ (crystal violet, Nile blue and rhodamine B) have been studied.

\section{MATERIALS AND METHODS}

\section{Samples and chemicals}

Ca-montmorillonite (SAz-1) from Arizona (USA) was used as host for the saturation with cationic dyes. The SAz-1 (denoted here as SAz) was supplied by Source Clays (The Clay Minerals Society, Purdue University, IN, USA). The fraction with grain size below $4.5 \mu \mathrm{m}$ was prepared from the original montmorillonite sample (M) by sedimentation and subsequent airdrying. The cation exchange capacity (CEC) of SAz is 1.40 meq. $\mathrm{g}^{-1}$ and specific surface area $93 \mathrm{~m}^{2} \cdot \mathrm{g}^{-1}$.

Four cationic dyes methylene blue (MB), crystal violet (CV), Nile blue (NB) and rhodamine B (RB), all supplied by Fluka, were used for the preparation of $\mathrm{CD} /$ montmorillonite complexes. $\mathrm{CD}$ formulas are shown in Figs. 1-4. The dyes were dissolved in distilled water, re-crystallized and dried under vacuum to constant mass. The solutions of $\mathrm{CD}$ for montmorillonite intercalation were prepared by dilution of the $5 \times 10^{-3} \mathrm{~mol}$ $\mathrm{dm}^{-3} \mathrm{CD}$ solution with distilled water. Precise concentrations of the dyes solutions were determined spectroscopically. 


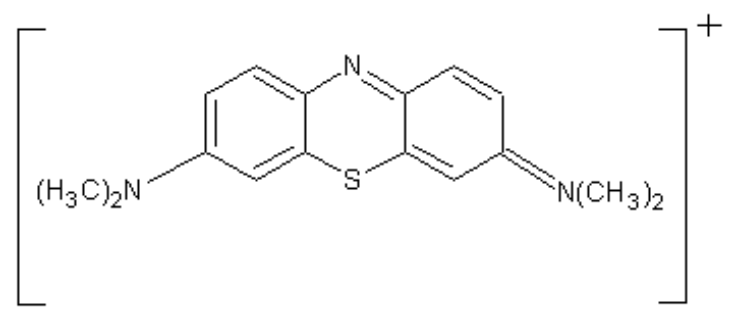

FIG. 1. Cation of methylene blue (MB).

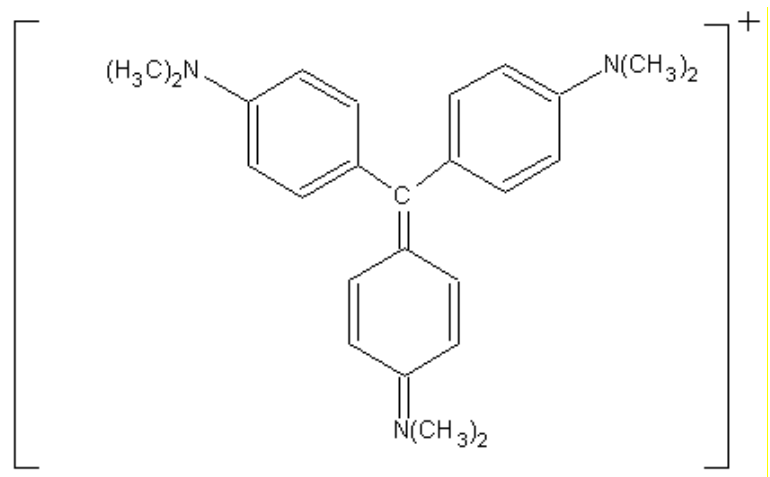

FIG. 2. Cation of crystal violet (CV).

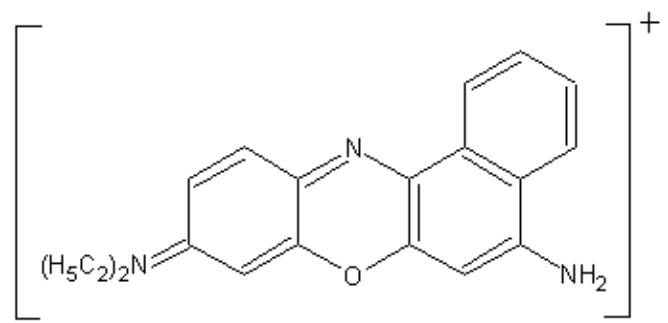

FIG. 3. Cation of Nile blue (NB). 


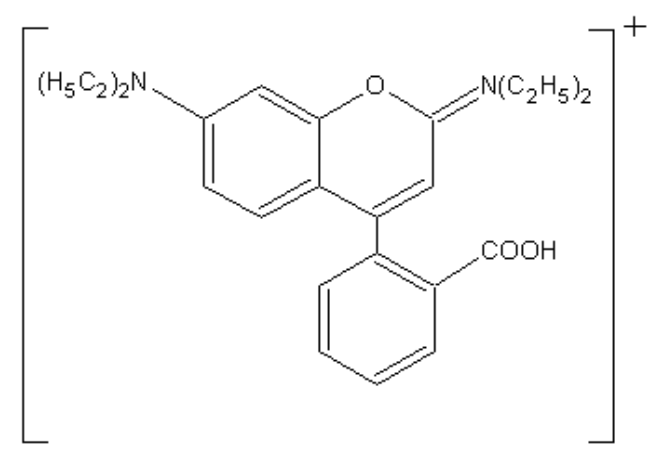

FIG. 4. Cation of rhodamine B (RB).

\section{Instruments and methods}

Absorption spectra of $\mathrm{CD}$ in aqueous solutions were recorded by UV-Vis spectrophotometer (Lambda 25, Perkin Elmer) using glass cells of 0.01 to $5 \mathrm{~cm}$ thickness at wavelength range $400-800 \mathrm{~nm}$.

For the fluorescence measurements the powder samples were placed on the quartz substrates. The fluorescence was excited using a $\mathrm{CW} \mathrm{He}-\mathrm{Cd}$ laser at $325 \mathrm{~nm}$. The $1 \mathrm{~mW}$ laser beam was focused by a $10 \mathrm{~cm}$ lens onto the front side of the sample; the fluorescence light was collected under $45^{\circ}$ geometry and focused on the entrance slit of the grating spectrograph with a CCD. The spectral resolution of the apparatus was about $0.5 \mathrm{~nm}$. The measurements were done at room temperatures $\left(20 \pm 2{ }^{\circ} \mathrm{C}\right)$.

The Vis electronic spectra of $\mathrm{CD} /$ montmorillonite complexes in solid state were recorded by diffuse reflectance spectra (DRS) method using a spectrometer (Perkin Elmer Lambda 35) equipped with an integrating sphere (Labsphere). The spectra of the montmorillonite powders were 
measured in circular cells with quartz windows between $400-900 \mathrm{~nm}$ with a $0.5 \mathrm{~nm}$ step.

The X-ray diffraction patterns were recorded by Bruker D8 Advance diffractometer (Bruker AXS, Germany) equipped with fast position sensitive detector VANTEC 1 under following conditions: the reflection mode, rotating sample holder and $\mathrm{CoK} \alpha$ irradiation. $\mathrm{LaB}_{6}$ was used as a calibration standard. Phase composition was evaluated using database PDF 2 Release 2004 (International Centre for Diffraction Data).

BET surface area measurements were performed on the Sorptomatic 1990 (Thermo-Finnigan) using adsorption of $\mathrm{N}_{2}$ at $77 \mathrm{~K}$. The residual moisture and adsorbed gases on the sample were removed by vacuum pump before measurement.

Cation exchange capacity of the montmorillonite samples was determined using the ion exchange reaction with barium chloride solutions (Czímerová et al., 2006). Concentrations of excess barium cations after equilibration were determined by atomic absorption spectrometry (Varian AA280FS).

\section{Preparation of reduced charge montmorillonite}

The $1 \mathrm{~g}$ of SAz portion (sample 1) was used to prepare the reduced charge montmorillonite (RC-SAz). This portion was shaken with $100 \mathrm{~cm}^{3}$ of $\mathrm{LiNO}_{3}$ solution $\left(1 \mathrm{~mol} \mathrm{dm}{ }^{-3}\right)$ at $20 \pm 2{ }^{\circ} \mathrm{C}$ for 2 hours at 200 oscillations per 
minute in the polypropylene vessel. Then solid/liquid phases were separated by centrifugation for $20 \mathrm{~min}$ at $4500 \mathrm{rpm}$. The solid sample was repeatedly shaken with fresh $\mathrm{LiNO}_{3}$ solution in order to get $\mathrm{Li}$ homoionic form of $\mathrm{SAz}$. The sample was washed with distilled water to remove nitrate ions and dried in vacuum. The reduced charge montmorillonite (RC-SAz(210); sample 6) was then prepared by heating of fully saturated $\mathrm{Li} / \mathrm{SAz}$ at $210{ }^{\circ} \mathrm{C}$ for 24 hours (Bujdák et al., 2002; Bujdák \& Komadel, 1997). The cation exchange capacity (CEC) and specific surface area of RC-SAz(210) were determined and they are $0.10 \mathrm{meq} \cdot \mathrm{g}^{-1}$ and $117 \mathrm{~m}^{2} \cdot \mathrm{g}^{-1}$, respectively.

Preparation of CD complexes with $S A z$ and $R C-S A z(210)$

Ca-montmorillonite $(\mathrm{SAz})$ and reduced charge montmorillonite heated at $210{ }^{\circ} \mathrm{C}(\mathrm{RC}-\mathrm{SAz}(210))$ were treated with selected cationic dyes.

$0.2 \mathrm{~g}$ of SAz sample was added to $100 \mathrm{~cm}^{3}$ of $5 \times 10^{-3} \mathrm{~mol} \mathrm{dm}{ }^{-3} \mathrm{CD}$ solution in a polypropylene vessel. The dispersion was shaken at $20 \pm 2{ }^{\circ} \mathrm{C}$ for 20 minutes at 200 oscillations per minute. Then solid and liquid phases were separated by centrifugation for $20 \mathrm{~min}$ at $4500 \mathrm{rpm}$. The solid sample was repeatedly shaken with fresh $\mathrm{CD}$ solution to get of fully saturated $\mathrm{CD} / \mathrm{SAz}$ sample. The solid was washed with distilled water and dried in vacuum (samples 2-5).

$0.2 \mathrm{~g}$ of RC-SAz(210) portion was added to $4 \mathrm{~cm}^{3}$ of $5 \times 10^{-4} \mathrm{~mol}$ $\mathrm{dm}^{-3} \mathrm{CD}$ solution in a polypropylene vessel. The dispersion was shaken at 
$20 \pm 2{ }^{\circ} \mathrm{C}$ for 20 minutes at 200 oscillations per minute and then centrifugation for $20 \mathrm{~min}$ at $4500 \mathrm{rpm}$ was performed. The $\mathrm{CD} / \mathrm{SAz}(210)$ sample was washed with distilled water and dried in vacuum (samples 7$10)$.

The labelling of the prepared montmorillonite samples is shown in

TABLE 1. The CD/montmorillonite complexes.

\begin{tabular}{|c|l|l|}
\hline Sample & Treatment of montmorillonite & Labelling \\
\hline 1 & Montmorillonite SAz-1 & $\mathrm{SAz}$ \\
\hline 2 & Montmorillonite fully saturated with MB $\left(5 \times 10^{-3} \mathrm{~mol} \mathrm{dm}^{-3}\right)$ & $\mathrm{MB} / \mathrm{SAz}$ \\
\hline 3 & Montmorillonite fully saturated with CV $\left(5 \times 10^{-3} \mathrm{~mol} \mathrm{dm}^{-3}\right)$ & $\mathrm{CV} / \mathrm{SAz}$ \\
\hline 4 & Montmorillonite fully saturated with NB $\left(5 \times 10^{-3} \mathrm{~mol} \mathrm{dm}^{-3}\right)$ & $\mathrm{NB} / \mathrm{SAz}$ \\
\hline 5 & Montmorillonite fully saturated with RB $\left(5 \times 10^{-3} \mathrm{~mol} \mathrm{dm}^{-3}\right)$ & $\mathrm{RB} / \mathrm{SAz}$ \\
\hline 6 & $\mathrm{RC}-\mathrm{SAz}$ prepared from Li/SAz at $210{ }^{\circ} \mathrm{C}$ & $\mathrm{RC}-\mathrm{SAz}(210)$ \\
\hline 7 & $\mathrm{RC}-\mathrm{SAz}(210)$ with $10 \% \mathrm{MB}$ loading $\left(5 \times 10^{-4} \mathrm{~mol} \mathrm{dm}^{-3}\right)$ & $\mathrm{MB} / \mathrm{RC}-\mathrm{SAz}(210)$ \\
\hline 8 & $\mathrm{RC}-\mathrm{SAz}(210)$ with $10 \% \mathrm{CV}$ loading $\left(5 \times 10^{-4} \mathrm{~mol} \mathrm{dm}^{-3}\right)$ & $\mathrm{CV} / \mathrm{RC}-\mathrm{SAz}(210)$ \\
\hline 9 & $\mathrm{RC}-\mathrm{SAz}(210)$ with $10 \% \mathrm{NB}$ loading $\left(5 \times 10^{-4} \mathrm{~mol} \mathrm{dm}^{-3}\right)$ & $\mathrm{NB} / \mathrm{RC}-\mathrm{SAz}(210)$ \\
\hline 10 & $\mathrm{RC}-\mathrm{SAz}(210)$ with $10 \% \mathrm{RB}$ loading $\left(5 \times 10^{-4} \mathrm{~mol} \mathrm{dm}^{-3}\right)$ & $\mathrm{RB} / \mathrm{RC}-\mathrm{SAz}(210)$ \\
\hline
\end{tabular}

Notes. Samples 2-5 were saturated with $5 \times 10^{-3} \mathrm{~mol} \mathrm{dm}^{-3} \mathrm{CD}$, samples 7-10 with $5 \times 10^{-4} \mathrm{~mol} \mathrm{dm}^{-3} \mathrm{CD}$. Percentages of CD loading in samples 7-10 are related to sample 6 . 


\section{RESULTS AND DISCUSSION}

Vis absorption spectra of cationic dyes in aqueous solution

The cationic dyes (CD) aggregate in aqueous solution; in the more concentrated dye solutions the higher aggregates occur (Klika, 1979; Stork et al., 1972; Stužka \& Hanuš, 1980; Selwyn \& Steinfeld, 1972). Except for rhodamine B (RB), which forms only dimers, all other studied dyes are also trimeric and probably even higher polymeric. The Vis absorption spectra of the cationic dyes are shown in Figs. 5A-D. The monomers of methylene blue (MB) have absorption maximum centred at $664 \mathrm{~nm}$, the dimers at 605 $\mathrm{nm}$ and the higher aggregates at even lower wavelengths (Fig. 5A). The absorption maximum of the monomers of crystal violet $(\mathrm{CV})$ is centred at $590 \mathrm{~nm}$, the dimers at $550 \mathrm{~nm}$ and higher aggregates at about $540 \mathrm{~nm}$ (Fig. 5B). The absorption spectra of Nile blue (NB) are shown in Fig. 5C. Similarly as for previous dyes, the wavelength of absorption bands of NB decreases with increasing aggregation (monomers $641 \mathrm{~nm}$; dimers $597 \mathrm{~nm}$; higher aggregates about $574 \mathrm{~nm}$ ). The aggregation of Nile blue is the highest from all presented CDs (Fig. 5). This observation is in agreement with the report by Stužka \& Hanuš (1980). They confirmed the formation of NB higher aggregates in aqueous solutions with concentration higher than $1.0 \times 10^{-5} \mathrm{~mol} \mathrm{dm}^{-3}$.

The aggregation of RB (monomers $554 \mathrm{~nm}$; dimers $524 \mathrm{~nm}$ ) and the isobestic point $(530 \mathrm{~nm})$ in Vis absorption spectra are shown in Fig. 5D. 

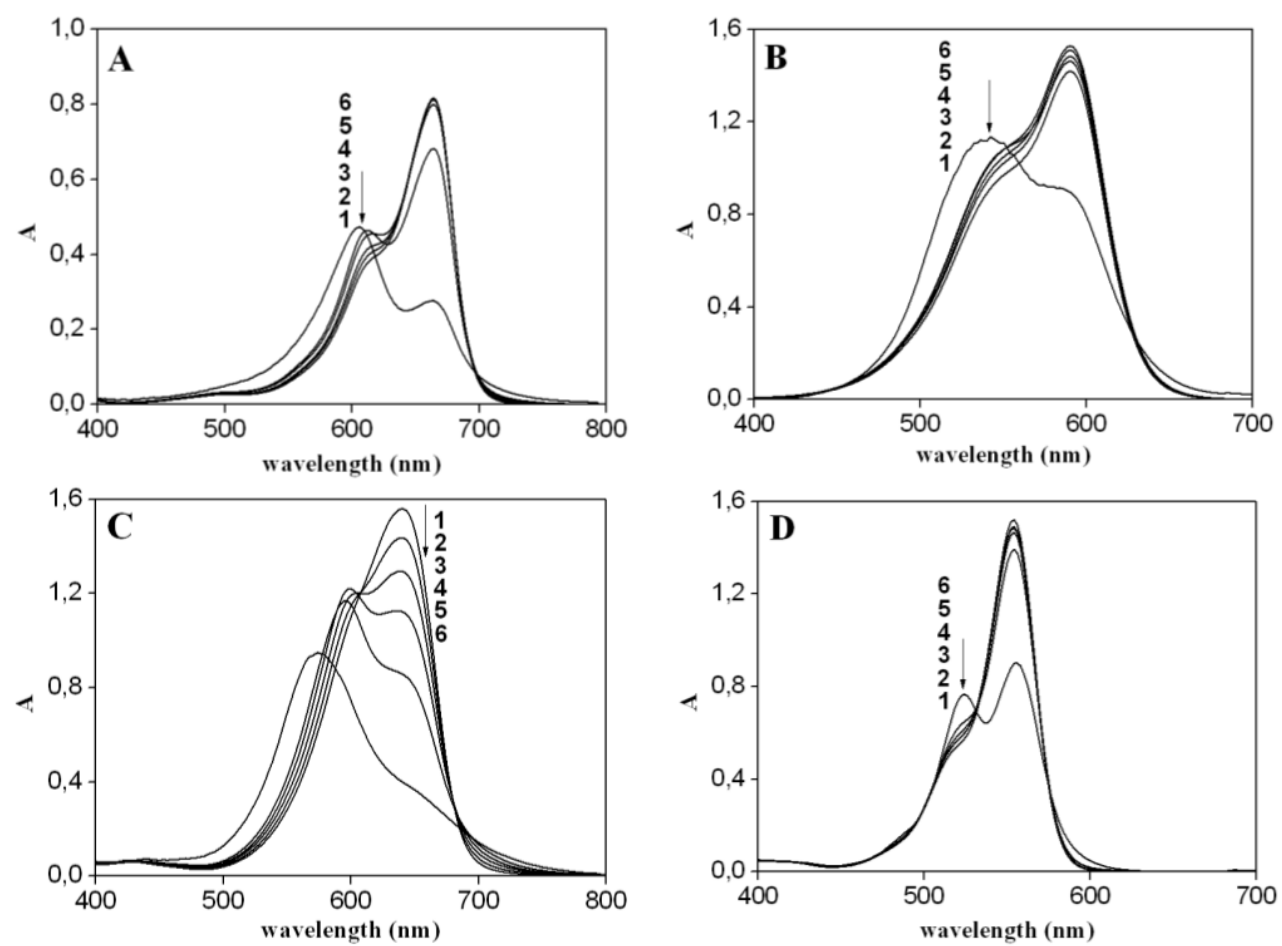

FIG. 5. Vis absorption spectra of cationic dyes in aqueous solution. A, Methylene blue; B, Crystal violet; C, Nile blue; D, Rhodamine B. spectrum $1-3.0 \times 10^{-6} \mathrm{~mol} \mathrm{dm}^{-3},(5 \mathrm{~cm}$ cell $)$; spectrum $2-7.5 \times 10^{-6} \mathrm{~mol}$ $\mathrm{dm}^{-3},(2 \mathrm{~cm}$ cell $)$; spectrum $3-1.5 \times 10^{-5} \mathrm{~mol} \mathrm{dm}^{-3},(1 \mathrm{~cm}$ cell $)$; spectrum 4 $3.0 \times 10^{-5} \mathrm{~mol} \mathrm{dm}^{-3},(0.5 \mathrm{~cm}$ cell $)$; spectrum $5-7.5 \times 10^{-5} \mathrm{~mol} \mathrm{dm}^{-3},(0.2 \mathrm{~cm}$ cell); spectrum $6-1.5 \times 10^{-3} \mathrm{~mol} \mathrm{dm}^{-3},(0.01 \mathrm{~cm}$ cell $)$.

Aggregation of cationic dyes in aqueous solution

The aggregation of cationic dyes (CD) in aqueous solution can be described by total (Eq. 1) or by stepwise (Eq. 2) chemical reactions: 


$$
\begin{aligned}
& n C D^{+} \stackrel{\leftarrow}{\leftarrow} C D_{n}^{n+} \\
& C D_{n-1}^{(n-1)+}+C D^{+} \underset{\leftarrow}{\longrightarrow} C D_{n}^{n+}
\end{aligned}
$$

where $n$ is the number of $\mathrm{CD}^{+}$monomers or the $n$-th $\mathrm{CD}$ aggregate. The equilibriums of Eq. (1) and Eq. (2) are given by Eq. (3) and (4), respectively.

$$
\begin{aligned}
& \beta_{n}=\frac{\left[C D_{n}^{n+}\right]}{\left[C D^{+}\right]^{n}} \\
& K_{n}=\frac{\left[C D_{n}^{n+}\right]}{\left.C D_{n-1}^{(n-1)+}\right] \cdot\left[C D^{+}\right]}
\end{aligned}
$$

where $\beta_{n}$ is total and $K_{n}$ stepwise equilibrium aggregation constants. The relations between $\beta_{n}$ and $K_{n}$ are as follows:

$$
\beta_{2}=K_{2} ; \quad \beta_{3}=K_{2} \cdot K_{3} ; \quad \beta_{4}=K_{2} \cdot K_{3} \cdot K_{4} ;
$$

The total analytical concentration of cationic dye $\left(c_{C D}\right)$ is then given by Eq. 5 as sum of equilibrium concentrations of not aggregated and aggregated CD species.

$$
c_{C D}=\sum_{n=1}^{4} n \cdot\left[C D_{n}^{n+}\right]
$$

The stepwise aggregation constants of $\mathrm{MB}, \mathrm{CV}, \mathrm{NB}$ and $\mathrm{RB}$ determined earlier are given in Table 2. As it has been demonstrated above the NB aggregation is the biggest of all here studied CD but Stužka \& Hanuš (1980) determined only $\mathrm{K}_{2}$ aggregation constant for the formation of NB dimers. Therefore a parameter model X (Ghosh \& Mukerjee, 1970) for the 
calculation of higher NB aggregation constants $\mathrm{K}_{3}$ and $\mathrm{K}_{4}$ and arithmetic mean of $K_{2}$ data of Stužka \& Hanuš (1980) were used. These calculated constants are given in parentheses in Table 2.

TABLE 2. The stepwise aggregation constants for used cationic dyes.

\begin{tabular}{|l|l|l|l|l|}
\hline Cationic dye & $\mathrm{K}_{2}\left(\mathrm{dm}^{3} \mathrm{~mol}^{-1}\right)$ & $\mathrm{K}_{3}\left(\mathrm{dm}^{3} \mathrm{~mol}^{-1}\right)$ & $\mathrm{K}_{4}\left(\mathrm{dm}^{3} \mathrm{~mol}^{-1}\right)$ & Source \\
\hline MB & $\begin{array}{l}2.54 \times 10^{3} \\
2.09 \times 10^{3}\end{array}$ & $\begin{array}{l}1.35 \times 10^{3} \\
4.00 \times 10^{3}\end{array}$ & $\begin{array}{l}2.06 \times 10^{2} \\
3.00 \times 10^{3}\end{array}$ & $\begin{array}{l}\text { Klika, 1979 } \\
\text { Ghosh \& Mukerjee, } 1970\end{array}$ \\
\hline CV & $6.80 \times 10^{2}$ & $7.30 \times 10^{2}$ & & Lueck et al., 1992 \\
\hline NM & $2.34 \times 10^{5}$ & $\left(2.34 \times 10^{5}\right)$ & $\left(2.34 \times 10^{5}\right)$ & Stužka \& Hanuš, 1980 \\
\hline RB & $1.43 \times 10^{3}$ & & & Klika et al., 2004 \\
\hline
\end{tabular}

The percentages of $\mathrm{CD}$ species for different concentrations of $\mathrm{CD}$ in aqueous solution have been calculated using Eqs. (3), (4) and (5) and aggregation constants (Table 2). The arithmetic mean of stepwise aggregation constants of Klika (1979) and Ghosh \& Mukerjee (1970) were used to calculate MB distribution. The calculated data are plotted in Figs. 6A-D.
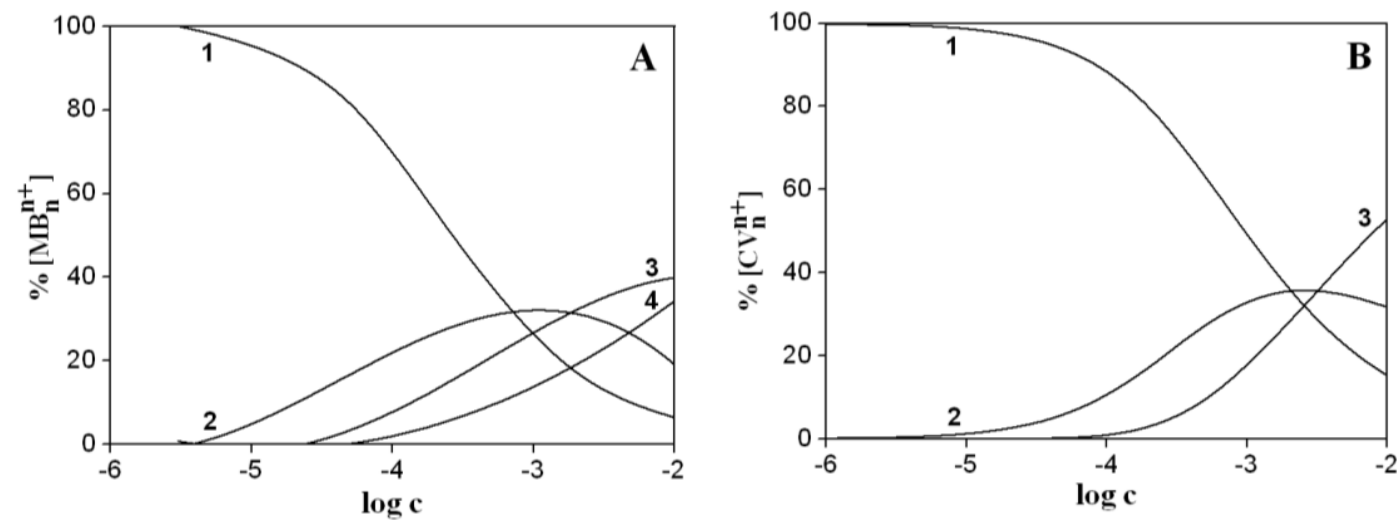

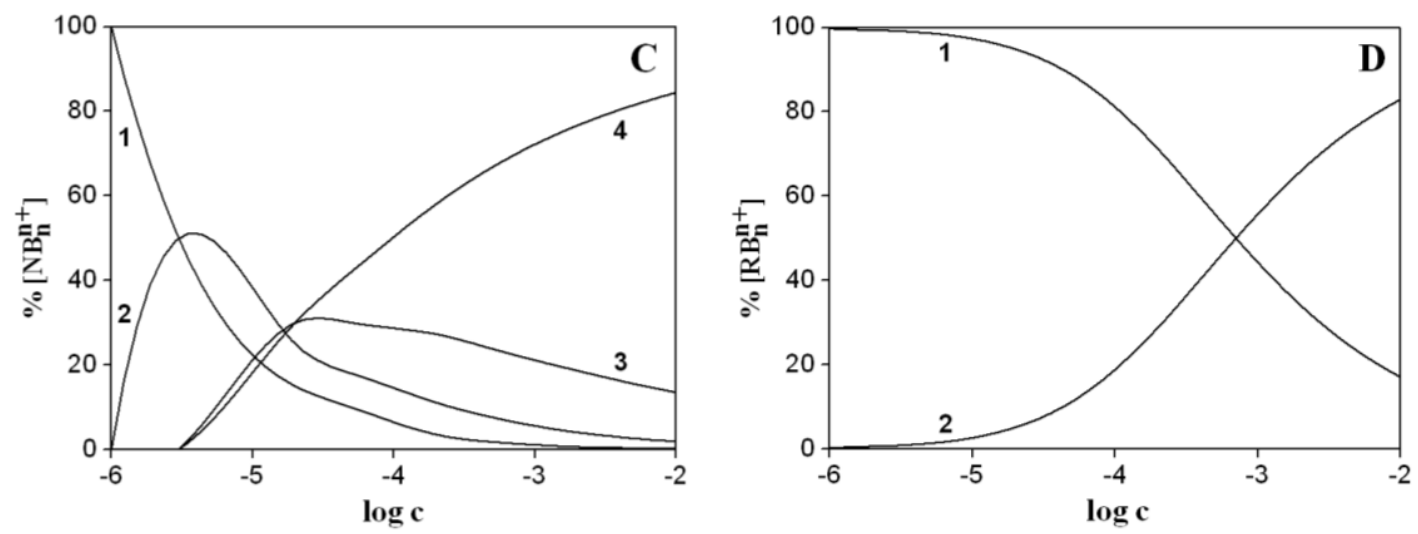

FIG. 6. Percentages of CD aggregates in aqueous solution for different analytical concentrations of $\mathrm{CD}\left(c\right.$; in mol $\left.\mathrm{dm}^{-3}\right)$. A, methylene blue; $\mathrm{B}$, crystal violet; C, Nile blue; D, rhodamine B.

The distributions of $\mathrm{MB}$ and $\mathrm{CV}$ monomers, dimers and trimers are very similar (Figs. 6A and 6B). The first formation of dimers appears at about $3 \times 10^{-6} \mathrm{~mol} \mathrm{dm}^{-3} \mathrm{CD}$ and trimers at about $2-5 \times 10^{-5} \mathrm{~mol} \mathrm{dm}^{-3} \mathrm{CD}$. The aggregation of $\mathrm{MB}$ is more extensive and therefore also $\mathrm{MB}$ tetramers are formed.

As it has been already mentioned above that NB aggregation is the highest from all presented CDs (see also Fig. 6C). The formation of NB dimers can be observed already at $1 \times 10^{-6} \mathrm{~mol} \mathrm{dm}^{-3}$ and its trimers and tetramers already at $3 \times 10^{-6} \mathrm{~mol} \mathrm{dm}^{-3} \mathrm{NB} ; 50 \%$ tetramers appears already in $\mathrm{NB}$ aqueous solution with analytical concentration of $1 \times 10^{-4} \mathrm{~mol} \mathrm{dm}^{-3} \mathrm{NB}$.

$\mathrm{RB}$ has the simplest distribution of species forming only monomers and dimers (Fig. 6D). 
Fluorescence spectra

Recently Klika et al. (2009) has discovered that complexes of reduced charge montmorillonite with low methylene blue loading have huge fluorescence intensity after $325 \mathrm{~nm}$ laser excitation. To verify whether also other CDs have similarly huge fluorescence, new experiments were performed. For this study the CD/RC-SAz(210) complexes with $10 \% \mathrm{CD}$ loading using $5 \times 10^{-4} \mathrm{~mol} \mathrm{dm}^{-3} \mathrm{CD}$ solutions were prepared. Reference $\mathrm{CD} / \mathrm{SAz}$ complexes (original $\mathrm{SAz}$ fully saturated by $5 \times 10^{-3} \mathrm{~mol} \mathrm{dm}^{-3}$ cationic dye) were used for comparison. The fluorescence spectra of all complexes are shown in Figs. 7A-D.
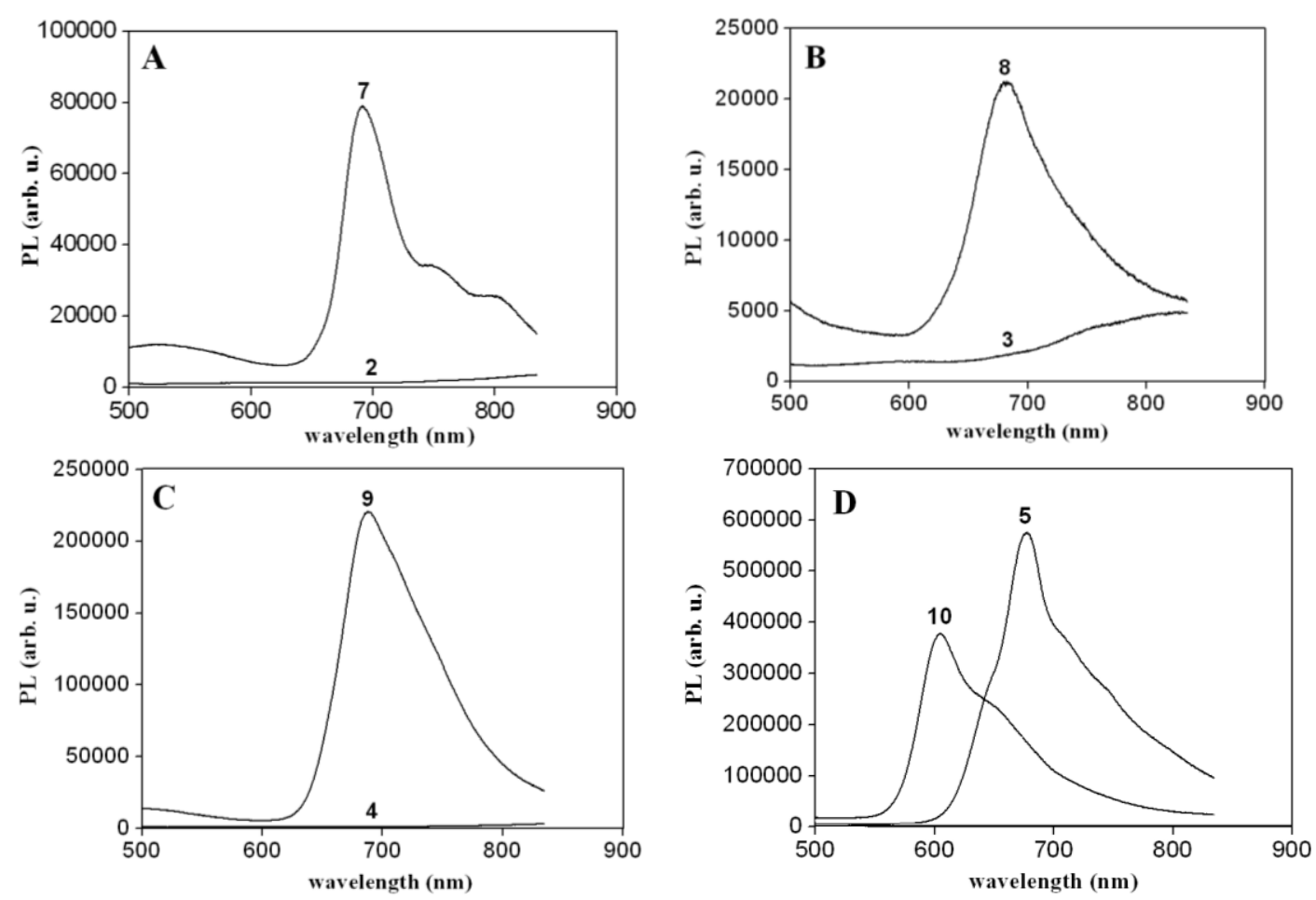
FIG. 7. Fluorescence spectra of $\mathrm{CD} / \mathrm{SAz}$ (samples 2, 3, 4 and 5) and fluorescence spectra of $\mathrm{CD} / \mathrm{RC}-\mathrm{SAz}(210)$ (samples 7, 8, 9 and 10). A, Methylene blue; B, Crystal violet; C, Nile blue; D, Rhodamine B.

The fluorescence intensities of fully saturated $\mathrm{CD} / \mathrm{SAz}$ complexes by methylene blue, crystal violet and Nile blue (spectra of samples 2, 3 and 4 in Figs. 7A, B and C, respectively) are very low. It is due to strong aggregation of the cationic dyes in more concentrated aqueous solution (see Figs. 5A-C). The aggregation of $\mathrm{CD}$ is known to effective quench the fluorescence (Endo et al., 1988; Klika et al., 2009). In contrast to spectra 2, 3 and 4 the fluorescence spectrum of sample 5 in Fig. 7D shows very high intensity; it is because the RB is fluorescence cationic dye by itself (Klika et al., 2004). Also imperfect, twisted dimer sandwiches with the distortion angle higher than $55^{\circ}$ could exhibit intensive fluorescence band with maximum at longer wavelength than the monomer band as it was demonstrated by Sasai et al. (2004) for rhodamine 6G/montmorillonite complex.

The aggregation of dyes is suppressed by their deposition on montmorillonite with reduced layer charge RC-SAz(210) and by low (10\%) CD loading (Klika et al., 2009). That is why the fluorescence intensity of the CD/RC-SAz(210) complexes (spectra of samples 7, 8 and 9 in Figs. 7A, $\mathrm{B}$ and $\mathrm{C}$, respectively) increases after laser excitation by several orders of magnitude. The maximal wavelength of these spectra (samples 7, 8 and 9) 
varies from 680 to $700 \mathrm{~nm}$. The fluorescence intensity of RB/RC-SAz(210) complex (spectrum of sample 10, Fig. 7D) is lower than that of fully saturated $\mathrm{RB} / \mathrm{SAz}$ complex (spectrum of sample 5). There is also a big difference between the maximal wavelengths of fluorescence bands for samples 5 and $10(680 \mathrm{~nm}$ for RB/SAz and $610 \mathrm{~nm}$ for RB/RC-SAz(210)). As described above the intensive fluorescence band at $680 \mathrm{~nm}$ of $\mathrm{RB} / \mathrm{SAz}$ complex (sample 5) could be due to the formation of imperfect sandwiches of RB dimers.

The maximum of fluorescence intensity could be somewhat different (higher) from those that were determined in this paper if the conditions of preparation (e.g. concentration of dye in saturated solution, dye loading) have changed.

XRD data

The structural layers of the montmorillonite, i.e. the basal spacing $\left(\mathrm{d}_{001}\right)$ of SAz substantially expands at high CD loading (Fig. 8). The basal distance is $1.51 \mathrm{~nm}$ in the original SAz (sample 1), $1.80 \mathrm{~nm}$ in $\mathrm{MB} / \mathrm{SAz}$ (sample 2), $2.08 \mathrm{~nm}$ in CV/SAz (sample 3), $1.68 \mathrm{~nm}$ in NB/SAz (sample 4), and $1.90 \mathrm{~nm}$ in $\mathrm{RB} / \mathrm{SAz}$ (sample 5). The increase of the basal spacing is due to the intercalation of $\mathrm{CD}$ into the SAz interlayer. The basal spacing of the $\mathrm{CV}$ and $\mathrm{RB}$ complexes are larger because of a larger size of these $\mathrm{CD}$ molecules - they have as much as 3 dimethylamino groups (CV) and 2 
diethylamino groups (RB) on the aromatic skeletons of similar size of all four CDs. The increase of the basal spacing of the intercalates shows that CDs are aggregated and/or tilted in the interlayer space.

The decrease of the original interlayer spacing $\left(\mathrm{d}_{001}\right)$ of SAz (sample 1) from $1.51 \mathrm{~nm}$ to $0.96 \mathrm{~nm}$ of $\mathrm{RC}-\mathrm{SAz}(210)$ (sample 6) is due to the reduction of SAz charge by Hofmann-Klemen effect (Hofmann \& Klemen, 1950) which removes almost all hydrated interlayer cations from the original smectite. After the low CD loading and the formation of the $\mathrm{CD} / \mathrm{RC}-\mathrm{SAz}(210)$ complexes the interlayer spacings of samples 7-10 are very close to that of the parent smectite (sample 6) proving that CD has not been intercalated. It can be supposed that $\mathrm{CDs}$ in $\mathrm{CD} / \mathrm{RC}-\mathrm{SAz}(210)$ complexes (samples 7-10) are mainly adsorbed on the outer surface of RC$\mathrm{SAz}(210)$ samples.

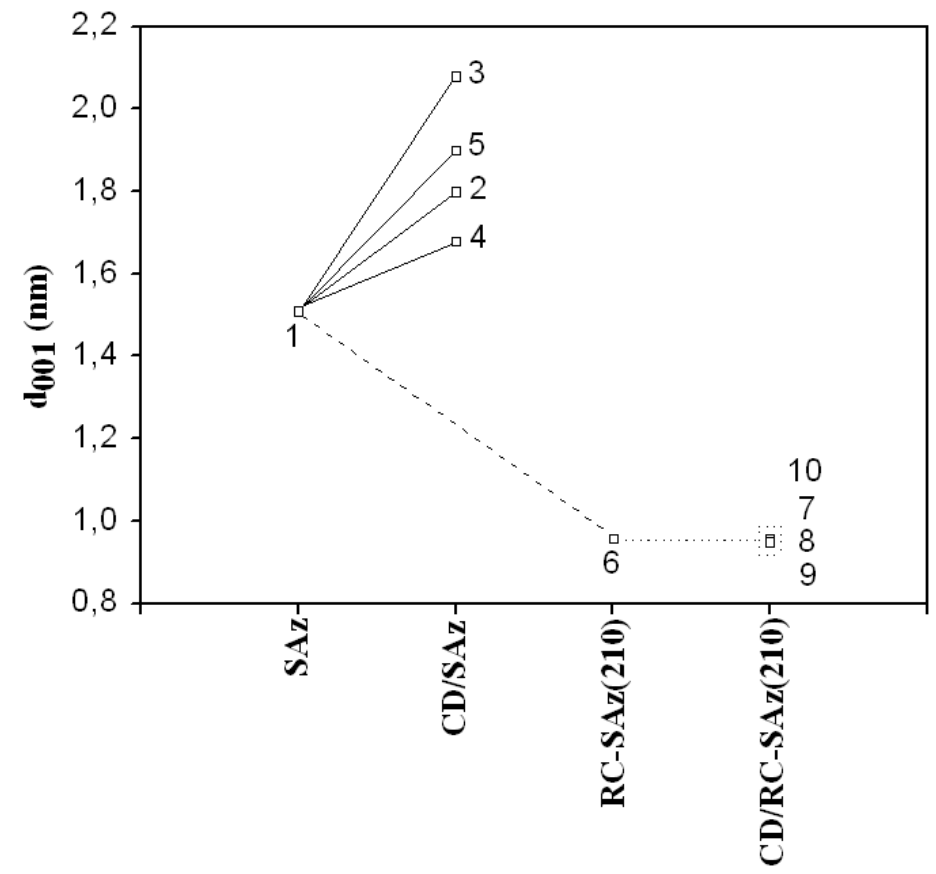


FIG. 8. Interlayer spacing $\left(\mathrm{d}_{001}\right)$ of samples 1-10. (For samples see Table 1.)

\section{Vis electronic spectra}

The diffuse reflectance Vis spectroscopy was used to study of CD species in montmorillonite complexes. The recorded spectra of prepared complexes are given in Fig. 9. In Vis electronic spectra of fully saturated $\mathrm{CD} / \mathrm{SAz}$ complexes H-aggregates (head-to-head association) prevail with maximal wavelength $526 \mathrm{~nm}$ for $\mathrm{NB} / \mathrm{SAz}$ (spectrum 4), $520 \mathrm{~nm}$ for $\mathrm{MB} / \mathrm{SAz}$ (spectrum 2) and $480 \mathrm{~nm}$ for complex $\mathrm{CV} / \mathrm{SAz}$ (spectrum 3). The maximum of absorption bands of $\mathrm{H}$-aggregates are shifted to shorter wavelength compared them with wavelengths of $\mathrm{H}$-aggregates present in aqueous solution (see Fig. 5). The next absorption band of fully saturated $\mathrm{CD} / \mathrm{SAz}$ complexes (spectra 2, 3 and 4) is broad and asymmetric with maximal wavelength at about $710 \mathrm{~nm}$ for NB/SAz (spectrum 4), $690 \mathrm{~nm}$ for $\mathrm{MB} / \mathrm{SAz}$ (spectrum 2) and $650 \mathrm{~nm}$ for $\mathrm{CV} / \mathrm{SAz}$ (spectrum 3). We suppose that they respond to dye monomers. In contrast to dye monomers present in aqueous solution they are shifted to longer wavelength. The bathochromic shift of monomeric band is induced by adsorption of dye into the interlayer space of montmorillonite (Yariv \& Nasser, 1990; Cenens \& Schoonheydt, 1988).

Vis electronic spectrum of RB/SAz complex (spectrum 5) has not very good distinguishable absorption maxima. Probably the absorption band 
of dye monomer (about $560 \mathrm{~nm}$ ) and band related to imperfect sandwiches of RB dimers (about $600 \mathrm{~nm}$ ) could be distinguished.

In $\mathrm{CD} / \mathrm{RC}-\mathrm{SAz}(210)$ complexes (spectra 7, 8, 9 and 10) the monomer species prevail. The intensities of absorption bands as well as their number are both much lower in contrast to $\mathrm{CD} / \mathrm{SAz}$. The most prominent absorption bands of the solid complexes (Fig. 9) have maxima close to those of the dye monomers in aqueous solutions (Fig.5). The maximal absorption bands of the monomers in solid complexes are at wavelengths about $664 \mathrm{~nm}$ for MB/RC-SAz(210) (spectrum 7), $640 \mathrm{~nm}$ for NB/RC-SAz(210) (spectrum 9), $590 \mathrm{~nm}$ for CV/RC-SAz(210) (spectrum 8) and $560 \mathrm{~nm}$ for RB/RC-SAz(210) (spectrum 10).

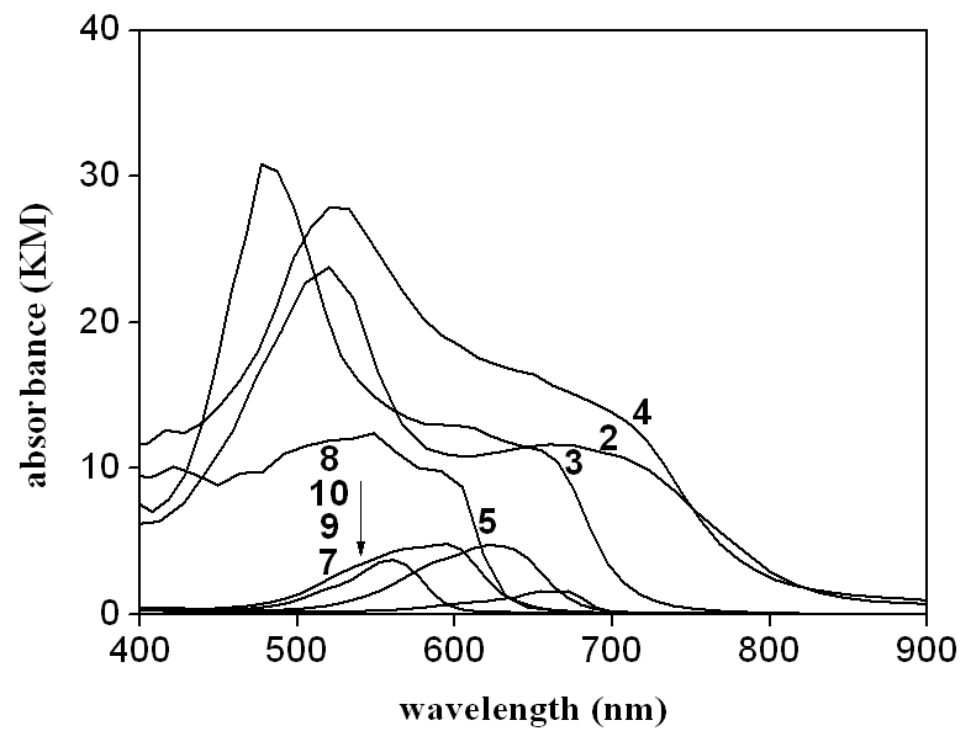

FIG. 9. Vis electronic spectra of solid state complexes of montmorillonite with cationic dye. (For samples see Table 1.)

CONCLUSION 
The fully saturated complexes of montmorillonite (SAz) with methylene blue, crystal violet and Nile blue have very poor fluorescence intensity due to the presence of $\mathrm{CD}$ higher aggregates in $\mathrm{CD} / \mathrm{SAz}$. As was shown before (Klika et al., 2009) the fluorescence intensity increases by several orders of magnitude if methylene blue is sorbed on the reduced charge montmorillonite $(\mathrm{MB} / \mathrm{RCM}(210))$. In this paper it was shown that crystal violet and Nile blue behave similarly and their adsorption on the reduced charge montmorillonite substantially enhances the fluorescence. The explanations of this phenomenon are threefold:

a) the charge density of the reduced charge smectite decreases and simultaneously the interlayer distance decreases from $1.51 \mathrm{~nm}$ to $0.96 \mathrm{~nm}$, which effectively closes the interlayer space for CD

b) low loading of the cationic dyes is on the outer surface of RC$\mathrm{SAz}(210)$, which decreases their intermolecular interactions, and

c) adsorbed dyes have parallel orientation with the outer surface of the smectite as it was shown by the molecular simulations of $\mathrm{MB}$ interactions with montmorillonites (Klika et al., 2009).

The low loading of methylene blue, crystal violet and Nile blue on the external surface causes the prevalence of monomeric forms of the dyes, which was demonstrated by diffuse reflectance Vis spectroscopy. 
In contrast to fully saturated complexes of montmorillonite (SAz) with methylene blue, crystal violet and Nile blue the fully saturated complexes of montmorillonite (SAz) with rhodamine B shows very high fluorescence intensity. It is due to the absence of rhodamine B higher aggregates and probably also due to the presence of imperfect, twisted sandwiches of rhodamine $B$ dimers that probably do not quench fluorescence of prevailing dye monomers. This explanation is supported by observation of Sasai et al. (2004) that described imperfect, twisted sandwiches of rhodamine $6 \mathrm{G}$ dimers in rhodamine $6 \mathrm{G} /$ montmorillonite complex with high fluorescence.

\section{ACKNOWLEDGEMENTS}

The authors are grateful for support of Ministry of Education of the Czech Republic (projects SV 6150011/2101, MSM 6198910016 and IP 4400011), Regional Material Science and Technology Centre (project CZ.1.05/2.1.00/01.0040) and Grant Agency of the Czech Republic (GACR 205/08/0869). Our thanks also belong to Dr. Vlastimil Matějka for the recording of X-ray diffraction patterns and Dr. Kamil Lang for providing the access to the diffuse reflectance spectroscope.

\section{REFERENCE}


Alvero R., Alba M.D., Castro M.A. \& Trillo J.M. (1994) Reversible migration of lithium in montmorillonites. The Journal of Physical Chemistry, 98, 7848-7853.

Bergmann K. \& O'Konski C.T. (1963) A spectroscopic study of methylene blue monomer, dimer, and complexes with montmorillonite. The Journal of Physical Chemistry, 67, 2169-2177.

Bujdák J. \& Komadel P. (1997) Interaction of methylene blue with reduced charge montmorillonite. Journal of Physical Chemistry B, 101, 90659068.

Bujdák J., Janek M., Madejová J. \& Komadel P. (1998) Influence of the layer charge density of smectites on the interaction with methylene blue. Journal of the Chemical Society, Faraday Transactions, 94, 3487-3492.

Bujdák J., Janek M., Madejová J. \& Komadel P. (2001) Methylene blue interactions with reduced-charge smectites. Clays Clay Minerals, 49, 244-254.

Bujdák J., Iyi N. \& Fujita T. (2002) The aggregation of methylene blue in montmorillonite dispersions. Clay Minerals, 37, 121-133.

Bujdák J. (2006) Effect of the layer charge of clay minerals on optical properties of organic dyes. Applied Clay Science, 34, 58-73.

Czímerová A., Bujdák J. \& Dohrmann R. (2006) Traditional and novel methods for estimating the layer charge of smectites. Applied Clay Science, 34, 2-13. 
Čeklovský A., Czímerová A., Pentrák M. \& Bujdák J. (2008) Spectral properties of TMPyP intercalated in thin films of layered silicates. Journal of Colloid Interface Science, 324, 240-245.

Dobrogowska C., Hepler L.G., Ghosh D.K. \& Yariv S. (1991) Metachromasy in clay mineral systems. Spectrophotometric and calorimetric study of the adsorption of crystal-violet and ethyl violet by Na-montmorillonite and by Na-kaolinite. Journal of Thermal Analysis and Calorimetry, 37, 1347-1356.

Endo T., Sato T. \& Shimada M. (1986) Fluorescence properties of the dyeintercalated smectite. Journal of Physics and Chemistry of Solids, 47, 799-804.

Endo T., Nakada N., Sato T. \& Shimada M. (1988) Fluorescence of clayintercalated xanthene dyes. Journal of Physics and Chemistry of Solids, 49, $1423-1428$.

Ghosh A.K. \& Mukerjee P. (1970) Multiple association equilibria in the self-association of methylene blue and other dyes. Journal of the American Chemical Society, 92, 6408-6412.

Hofmann U. \& Klemen R. (1950) Verlust der Austauschfähigkeit von Lithiumionen an Bentonit durch Erhitzung. Zeitschrift für anorganische und allgemeine Chemie, 262, 95-99.

Klika Z. (1979) Studium polymerace methylenové modře ve vodných roztocích. Sborník vědeckých prací VŠB-TU Ostrava, 2, 53-70. 
Klika Z., Weissmannová H., Čapková P. \& Pospíšil M. (2004) The rhodamine B intercalation of montmorillonite. Journal of Colloid Interface Science, 275, 243-250.

Klika Z., Čapková P., Horáková P., Valášková M., Malý P., Macháň R. \& Pospíšil. M. (2007) Composition, structure, and luminescence of montmorillonites saturated with different aggregates of methylene blue. Journal of Colloid Interface Science, 311, 14-23.

Klika Z., Pustková P., Praus P., Kovář P., Pospíšil M., Malý P., Grygar T., Kulhánková L. \& Čapková P. (2009) Fluorescence of reduced charge montmorillonite complexes with methylene blue: Experiments and molecular modeling. Journal of Colloid Interface Science, 339, 416-423.

Komadel P., Madejová J. \& Bujdák J. (2005) Preparation and properties of reduced-charge smectites. Clays Clay Minerals, 53, 313-334.

Lueck H.B., Bobbie L. \& McHale J.L. (1992) Aggregation of triphenylmethane dyes in aqueous solution: dimerization and trimerization of crystal violet and ethyl violet. Spectrochimica Acta Part A: Molecular and Biomolecular Spectroscopy, 48, 819-828.

Madejová J. (2005) Studies of reduced-charge smectites by near infrared spectroscopy. Pp. 169-202 in: The application of vibrational spectroscopy to clay minerals and layered double hydroxides, CMS Workshop Lectures (J.T. Kloprogge, editor). The Clay Mineral Society, USA. 
Martynková G.S., Kulhánková L., Malý P. \& Čapková P. (2008) Fluorescence and structure of methyl red-clay nanocomposites. Journal of Nanoscience and Nanotechnology, 8, 2069-2074.

Salleres S., Arbeloa F.L., Martínez V.M., Arbeloa T. \& Arbeloa I.L. (2009) Improving the fluorescence polarization method to evaluate the orientation of fluorescent systems adsorbed in ordered layered materials. Journal of Luminescence, 129, 1336-1340.

Sasai R., Iyi N., Fujita T., Arbeloa F.L., Martínez V.M., Takagi K. \& Itoh H. (2004) Luminescence properties of rhodamine 6G intercalated in surfactant/clay hybrid thin solid films. Langmuir, 20, 4715-4719.

Selwyn J.E. \& Steinfeld J.I. (1972) Aggregation equilibria of xanthene dyes. The Journal of Physical Chemistry, 76, 762-774.

Stork W.H.J., Lippits G.J.M. \& Mandel M. (1972) Association of crystal violet in aqueous solutions. The Journal of Physical Chemistry, 76, 17721775.

Stužka V. \& Hanuš V. (1980) Spectrophotometric study of polymerization of Nile Blue A. Acta Universitatis Palackianae Olomucensis, 65, 139153.

Su Ch.-Ch. \& Shen Y.-H. (2005) Preparation and dispersive behaviors of reduced charge smectite. Colloids and Surfaces A: Physicochemical and Engineering Aspects, 259, 173-177. 
Villemure G., Detellier C. \& Szabo A.G. (1986) Fluorescence of clayintercalated methylviologen. Journal of the American Chemical Society, 108, 4658- 4659 .

Yariv S. \& Nasser A. (1990) Metachromasy in clay minerals. Spectroscopic study of the adsorption of crystal violet by laponite. Journal of the Chemical Society, Faraday Transactions, 86, 1593-1598. 